\title{
Effects of organic perturbation on marine sediment betaproteobacterial ammonia oxidizers and on benthic nitrogen biogeochemistry
}

\author{
A. Bissett ${ }^{1,2,6, *}$, P. L. M. Cook $^{3}$, C. Macleod ${ }^{4}$, J. P. Bowman ${ }^{2}$, C. Burke ${ }^{1,5}$ \\ ${ }^{1}$ School of Aquaculture, Launceston, Australia and ${ }^{2}$ School of Agricultural Science, University of Tasmania, Hobart, \\ Tasmania 7001, Australia \\ ${ }^{3}$ Water Studies Centre, Monash University, Clayton, Victoria 3800, Australia \\ ${ }^{4}$ Tasmanian Aquaculture and Fisheries Institute (TAFI), Marine Research Laboratories, Nubeena Crescent, Taroona, \\ Tasmania 7053, Australia \\ ${ }^{5}$ National Centre for Marine Conservation and Resource Sustainability (NCMCRS), Australian Maritime College, \\ University of Tasmania, Hobart, Tasmania 7001, Australia \\ ${ }^{6}$ Present address: CSIRO Plant Industry, GPO Box 1600, Canberra, ACT, 2601 Australia
}

\begin{abstract}
The failure of denitrification to remove nitrogen build-up from aquatic systems is often attributed to sediment chemical conditions inhibiting nitrification and therefore the supply of suitable substrates to be denitrified. We investigated the effects of organic fish farm pollution on nitrogencycle dynamics and betaproteobacterial ammonia-oxidizing bacteria ( $\beta$-AOB) community structure to elucidate the potential role of the nitrifier community on nitrogen biogeochemistry in marine sediments. Porewater nitrogen concentrations, denitrification rates, $\beta$-AOB 16S rDNA gene quantification, denaturing gradient gel electrophoresis (DGGE) community fingerprints and infaunal counts were determined in samples collected from beneath fish cages and at adjacent, non-impacted control sites. The study was conducted over 2 full, 1 yr production cycles. Although nitrogen cycling was significantly altered beneath cages, changes appeared to result from a reduction in the proportion of ammonia nitrified rather than from inhibition of nitrification per se. DGGE revealed $\beta$-AOB communities shifted rapidly and remained diverse at both cage and reference sites. Quantitative PCR (qPCR) showed $\beta$-AOB numbers did not decline in absolute terms but did decline as a proportion of the total bacterial community at cage sites and at the end of the stocking periods. Sediment infaunal community analysis showed significant effects of organic loading and indicated more bioirrigation at impacted sites. Despite the induction of conditions thought to be detrimental to nitrification and to $\beta$ AOB (low oxygen, reduced sediments, low $\mathrm{pH}$, and high sulphide concentrations), these communities remained diverse and apparently viable, perhaps a result of heavy sediment bioirrigation. However, despite the increase in denitrification, nitrogen left the sediment predominantly as ammonia, thus producing potential point sources of eutrophication.
\end{abstract}

KEY WORDS: Eutrophication · Nitrification · Denitrification · Sediment · Ammonia-oxidising bacteria Resale or republication not permitted without written consent of the publisher

\section{INTRODUCTION}

Anthropogenic impacts cause widespread alterations to the diversity and function of marine communities, which may in turn affect ecological functions performed by these communities. Eutrophication of coastal waters is one such impact that may adversely influence how benthic ecosystems function to produce healthy waterways. Intensive salmon cage culture leads to localized pollution of the underlying sediments by the accumulation of organic waste materials (e.g. uneaten food, faeces) and, therefore, may alter sediment community structure and function (McCaig et al. 1999, Christensen et al. 2000, Bissett et al. 2007). The point source nature of organic loading from fish farms renders them ideal sites to study effects of sedi- 
ment organic pollution. A major constituent of salmon diets is protein. The outputs of farms are therefore high in nitrogen content (McCaig et al. 1999). As nitrogen is the major limiting nutrient for marine phytoplankton growth, the possible eutrophication effects of fish farm pollution are of general environmental concern (Christensen et al. 2000).

Eutrophication effects may be ameliorated by processes that reduce the build-up of fixed nitrogen by expelling $\mathrm{N}_{2}$ gas from the system, for example via denitrification (Blackburn \& Blackburn 1992). Denitrification requires the supply of oxidized nitrogen species, and previous studies have shown variation in the level of coupling between nitrification and denitrification (Jensen et al. 1996, Dong et al. 2000, Magalhães et al. 2005). Decoupling can occur when $\mathrm{NO}_{3}{ }^{-}$concentrations in overlying water are sufficient to support sediment denitrification. When $\mathrm{NO}_{3}{ }^{-}$for denitrification is primarily supplied by nitrification, then any impediment to nitrification will also impede nitrogen removal from the sediments by limiting available $\mathrm{NO}_{3}{ }^{-}$. Nitrification is carried out by a less diverse group of organisms than denitrification (Wertz et al. 2007) and is affected by adverse environmental conditions. The main factors that affect nitrification rates are ammonia, carbon dioxide, oxygen and sulphide concentrations, temperature, salinity and pH (Macdonald 1986, Joye \& Hollibaugh 1995, Kowalchuk et al. 1998). Conditions of low oxygen, reduced sediments, low $\mathrm{pH}$, and high sulphide concentrations are often associated with fish farm sediments (Wildish et al. 2003, Macleod et al. 2004, Bissett et al. 2007) and are thought to inhibit nitrification and, consequently, $\mathrm{N}$ removal.

Ammonia oxidation may be carried out by both bacterial and archaeal groups. Ammonia-oxidising Archaea (AOA) have been shown to be important in many environments where nitrification occurs, including many soils (Leininger et al. 2006, Nicol et al. 2008) and freshwater and marine sediments (Dang et al. 2008, Santoro et al. 2008). While we did not use nucleic acid techniques to assess the AOA in the sediments of this study, we did carry out lipid biomarker analysis. This analysis suggested that the AOA, identifiable as members of the phylum Crenarchaeota by isoprenoid glycerol dialkyl glycerol tetraethers, comprised only a minor component of the microbial community, and their biomass did not change in response to organic loading (Macleod et al. 2004).

The ammonia-oxidising bacteria (AOB) can also carry out the first rate-limiting step of nitrification (the oxidation of ammonia to nitrite) and fall into 2 monophyletic groups within the phylum Proteobacteria. The first contains the strains of Nitrosococcus oceanus, in the class Gammaproteobacteria, and the other contains the genera Nitrosomonas and Nitrosospira in the class Betaproteobacteria (Kowalchuk et al. 1997). The latter group, which form up to 7 clusters (McCaig et al. 1999), are common nitrifiers in marine systems, (Kowalchuk et al. 1997, McCaig et al. 1999) and were therefore the group investigated in this study.

The aim of this study was to assess the effects of highly labile organic loading on the sediment $\beta$-AOB community composition and its effect ultimately on nitrogen removal in these sediments. We hypothesized that organic carbon enrichment would alter $\beta$-AOB community composition and decrease $\beta$-AOB population density, thereby decreasing the supply of nitrate available for denitrification. We used biogeochemical techniques and 16S rRNA genes to monitor nutrient fluxes, denitrification, shifts in the $\beta$-AOB diversity and $\beta$-AOB numbers, and to identify some members of the sediment $\beta$-AOB community over 2 farm production cycles of 12 mo each in 2001 and 2002.

\section{MATERIALS AND METHODS}

Sample collection. Samples were collected during the period from 2000 to 2002 as described in Bissett et al. (2006). Briefly, sediments under a salmon (Salmo salar) farm and at adjacent control sites in the D'Entre-

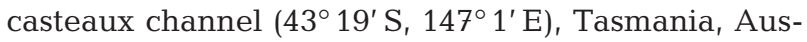
tralia were investigated. This site was studied previously and is referred to as Farm 2 in Bissett et al. (2006). The lease was situated in water 35 to $40 \mathrm{~m}$ deep and was primarily marine, although there was some riverine influence. The site was protected from most wave action and ocean swells. Sediments were predominantly silt-clays, and carbon content was approximately $3 \%$ (Macleod et al. 2004). This value increased to approximately 4 to $5 \%$ at cage sites during the trial (Macleod et al. 2004).

For molecular analysis, 6 sediment cores were randomly taken from 2 cage sites $(2$ cages $\times 3$ cores) and from 2 reference sites ( 2 cages $\times 3$ cores) situated $150 \mathrm{~m}$ from the edge of the study cages and perpendicular to the predominant water flow. Reference site sediments were at the same water depth and had the same particle size distribution as their respective cages. Sediments were sampled at the beginning and end of the 9 mo organic loading (fish stocked and fed) period and at the end of a 3 mo fallowing (no fish stocked) period, over two 12 mo cycles. Table 1 contains sampling design, date and labelling details. Sediment cores were collected using polyethylene tubes (150 mm diameter) and a Craib corer (Craib 1965). Cores were all at least $100 \mathrm{~mm}$ deep and showed no signs of physical disturbance. After collection, cores were stored in an ice cooler filled with ambient water for transfer to the laboratory. Within $6 \mathrm{~h}$, sediments from the cores were 
Table 1. Sampling design. Dates indicate months in which samples were taken; cage management and organic loading indicate whether cages held fish and supplied organic load to sediments; sampling time refers to months after the beginning of the study; and sample identification refers to the sample labelling scheme used. Analyses conducted are also listed, with X indicating that the analysis was completed at the indicated sampling time. Samples were collected from both cage and reference sites at all sampling times

\begin{tabular}{|c|c|c|c|c|c|c|c|c|}
\hline Date & Cage management & $\begin{array}{l}\text { Organic } \\
\text { loading }\end{array}$ & $\begin{array}{l}\text { Sampling } \\
\text { time (mo) }\end{array}$ & $\begin{array}{c}\text { Sample } \\
\text { identification }\end{array}$ & $\begin{array}{l}\text { Molecular } \\
\text { analysis }\end{array}$ & $\begin{array}{c}\text { Flux } \\
\text { analysis }\end{array}$ & $\begin{array}{l}\text { Nutrient } \\
\text { analysis }\end{array}$ & $\begin{array}{l}\text { Infauna } \\
\text { analysis }\end{array}$ \\
\hline Feb 01 & Beginning of stocking & No & 0 & None taken & & & & \\
\hline Apr 01 & & Yes & 2 & $\mathrm{~S} 1$ & $\mathrm{X}$ & $\mathrm{X}$ & $\mathrm{X}$ & $\mathrm{X}$ \\
\hline Jul 01 & & Yes & 6 & $\mathrm{~S} 2$ & & $\mathrm{X}$ & & \\
\hline Nov 01 & End of stocking & Yes & 9 & S3 & $\mathrm{X}$ & $\mathrm{X}$ & $\mathrm{X}$ & $\mathrm{X}$ \\
\hline Jan 02 & End of fallowing & No & 12 & $\mathrm{~S} 4$ & $\mathrm{X}$ & $\mathrm{X}$ & & $\mathrm{X}$ \\
\hline Feb 02 & Beginning of stocking & Yes & 12 & S5 & $\mathrm{X}$ & & & \\
\hline Nov 02 & End of stocking & Yes & 21 & S6 & $\mathrm{X}$ & & $\mathrm{X}$ & \\
\hline Feb 03 & End of fallowing & No & 24 & $\mathrm{~S} 7$ & $\mathrm{X}$ & & $\mathrm{X}$ & $\mathrm{X}$ \\
\hline
\end{tabular}

pushed upwards and the top $1 \mathrm{~cm}$ removed for molecular and nutrient analyses. Cores for nutrient analysis were sliced at $0.5,1.0,1.5,2.0,3.0,4.0,6.0$ and $8.0 \mathrm{~cm}$ and the porewater extracted from each slice (e.g. 0 to $0.5 \mathrm{~mm}$ et seq). Samples for molecular analysis were stored frozen at $-20^{\circ} \mathrm{C}$, and DNA was extracted within 2 mo of sampling. Nutrient samples also stored at $-20^{\circ} \mathrm{C}$ until analysed.

For benthic flux analysis, 4 sediment cores were randomly taken from one cage and its adjacent reference site (referred to as Cage 1 and Reference 1 in the molecular analysis) in the same manner as that described above.

Infaunal sampling. A total of 5 replicate sediment cores were collected from all cage and reference sites using a Van Veen Grab (surface area $0.0675 \mathrm{~m}^{2}$ ) at sampling times S1, S3, S4 and S7 (Table 1). Grab contents were transferred to mesh bags (mesh size $0.875 \mathrm{~mm}$ ) and rinsed. Samples were then wet sieved to $1 \mathrm{~mm}$, and the retained material preserved in a solution of $10 \%$ formalin:seawater ( $4 \%$ formaldehyde). Samples were transferred to the laboratory for sorting and the infauna identified to the lowest possible taxonomic level and enumerated. The dominant infauna were categorised according to their biotubation potential as either sediment stabilsers, where their life histories indicated that they consolidate the sediments (e.g. sedentary tubiculous worms), or destabilisers, where they actively bioturbate the sediments (e.g. mobile burrowing worms).

Nutrient analyses. Samples were collected for nutrient analyses at S1, S3, S4 and S7 (Table 1) from one cage and reference site at $\mathrm{S} 1$ and all cage and reference sites at S2, S3 and S4. Nutrient concentrations were determined on $0.45 \mu \mathrm{m}$-filtered porewater, extracted under atmospheric conditions. Ammonia was determined according to Watson et al. (2005), nitrate and nitrite according to Grasshoff (1983) and total N modified from Valderrama (1981) with a $0.5 \mathrm{M}$ potassium persulfate digestion. The limits of detection for each analyte were: nitrite $=0.05 \mu \mathrm{M}$, nitrite + nitrate $=0.4 \mu \mathrm{M}$, ammonia $=0.4 \mu \mathrm{M}$ and total $\mathrm{N}=$ $45 \mu \mathrm{M}$.

Benthic fluxes and denitrification measurements. Benthic nutrient flux measurements were conducted over the first year of the study, S1, S2, S3 and S4 (Table 1). Measurements were made ex situ in 4 cores $(25 \times 14.5 \mathrm{~cm}$ internal diameter) per treatment collected from the study site. Upon return to the laboratory, the cores were submerged in water from the field site at in situ temperature in a temperature-controlled water bath and stirred, allowing a free exchange of water, and then left overnight to equilibrate. The following day, the cores were capped and 4 samples were taken for nutrients over a period of time, which allowed the dissolved $\mathrm{O}_{2}$ in the water to drop by ca. $20 \%$. Concentration changes over this period of time were linear. A 'blank' core containing only water was also incubated and sampled in an identical manner to the sediment cores. Water samples taken for nutrients and alkalinity were filtered through a precombusted Whatman GF/F filter into $10 \mathrm{ml}$ screw-cap polypropylene containers. They were stored frozen for later analysis within $3 \mathrm{mo}$. The flux across the sedimentwater interface under dark conditions was calculated using linear regression concentration versus time (Dalsgaard et al. 2000) and typically used 4 data points. Rates of denitrification were measured using the isotope pairing technique (Nielsen 1992) as described by Dalsgaard et al. (2000). After the nutrient flux measurements were completed, 4 subcores $(4.8 \mathrm{~cm}$ internal diameter $\times 30 \mathrm{~cm}$ ) were taken from the original cores such that there was ca. $8 \mathrm{~cm}$ of sediment and $17 \mathrm{~cm}$ of water column. A teflon-coated stirrer bar was then suspended ca. $5 \mathrm{~cm}$ above the sediment; this was driven by an external rotating magnet rotating at 60 to 
$70 \mathrm{rpm}$. Dark incubations were performed with 4 cores from each site on the following day. Experiments commenced with the addition of stock ${ }^{15} \mathrm{NO}_{3}{ }^{-}$to a final concentration of $60 \mu \mathrm{M}$. This concentration was chosen after a concentration series experiment as described by Risgaard Petersen \& Rysgaard (1995) had shown that concentrations of ${ }^{15} \mathrm{NO}_{3}{ }^{-}$above $20 \mu \mathrm{M}$ gave constant values of denitrification. Samples were taken for the analysis of $\mathrm{NO}_{3}{ }^{-}$before and after the addition of ${ }^{15} \mathrm{NO}_{3}{ }^{-}$ in order to calculate the final ${ }^{15} \mathrm{~N}$ enrichment. Cores were then capped and left for $2 \mathrm{~h}$ to allow the added ${ }^{15} \mathrm{NO}_{3}{ }^{-}$to diffuse into the denitrification zone and come to equilibrium. Cores were sacrificed over a time span that allowed the dissolved oxygen (DO) to drop by no more than $20 \%$ from saturation. They were sacrificed as follows: A total of $1 \mathrm{ml}$ of $50 \% \mathrm{ZnCl}_{2}$ was added to the water overlying the sediment before the sediment was gently slurried with the water column using a metal rod; Coarser particles were allowed to settle for about $1 \mathrm{~min}$ before a ca. $40 \mathrm{ml}$ sample was taken using a gas-tight syringe. The sample was then placed in a $12.5 \mathrm{ml}$ Exetainer (Labco) to which $250 \mu \mathrm{l}$ of $50 \% \mathrm{w} / \mathrm{v}$ $\mathrm{ZnCl}_{2}$ had been added. A headspace of He was introduced into the Exetainer within $2 \mathrm{wk}$, and the samples were then analysed using a Finnigan MAT Delta S isotope ratio mass spectrometer interfaced to a Hewlett Packard 5890 GC within several months. Denitrification rates were calculated according to the isotope pairing equations (Nielsen 1992).

DNA extraction and purification. DNA was extracted from sediment samples at S1, S3, S4, S5, S6 and S7 as described in Bissett et al. (2006). Briefly, bacterial genomic DNA was obtained by the bead beating method, modified from Purdy et al. (1996). Samples of sediment $(0.5 \mathrm{~g})$ were added to $2 \mathrm{ml}$ screw-cap tubes containing $0.5 \mathrm{~g}$ of $0.1 \mathrm{mM}$ zirconium-silica beads, $700 \mu \mathrm{l}$ of $120 \mathrm{mM}$ sodium phosphate ( $\mathrm{pH} 8.0), 1 \% \mathrm{w} / \mathrm{v}$ (weight to volume) acid washed polyvinylpolypyrrolidone, $500 \mu \mathrm{l}$ of Tris-equilibrated phenol and $50 \mu \mathrm{l}$ of $20 \% \mathrm{w} / \mathrm{v}$ sodium dodecyl sulfate. The samples were bead beaten (Mikrodismembrator U, B. Braun Biotech International) at $3800 \mathrm{rpm}$ for $3 \times 10 \mathrm{~s}$, with $30 \mathrm{~s}$ on ice between beatings. They were then centrifuged at $20800 \times g$ for 2 min and supernatants stored on ice. The sediment pellet was then resuspended in $700 \mu \mathrm{l}$ sodium phosphate buffer and bead beaten at $3800 \mathrm{rpm}$ for $20 \mathrm{~s}$, and centrifuged again. Supernatants were pooled. Nucleic acids were precipitated with ethanol and resuspended in $50 \mu \mathrm{l}$ of Milli-Q water. Extractions were then purified using the Prep-Agene DNA purification system (Bio-Rad Laboratories), according to the manufacturer's instructions. Final extractions were stored at $-20^{\circ} \mathrm{C}$.

Polymerase chain reaction. To avoid band doublets caused by redundant primers, a nested PCR approach was used to amplify 16S rRNA gene fragments from $\beta$ AOB (McCaig et al. 1999). First 16S rDNA gene fragments from $\beta$-AOB were amplified using a 1650 Air Thermo-Cycler (Idaho Technology) with the primers CTO 189fA/B (GAG RAA AGC AGG GGA TCG) and CTO 654r (CTA GCY TTG TAG TTT CAA ACG C) (Kowalchuk et al. 1997). PCR products obtained using $\beta$-AOB specific primers were then amplified using universal primers $357 \mathrm{f}$ with a GC clamp (CGC CCG CCG CGC CCC GCG CCC GGC CCG CCG CCC CCG CCC CCC TAC GGG AGG CAG CAG) and 518r (GTA TTA CCG CGG CTG CTG) (Muyzer et al. 1993). Reactions were performed using an Advantage 2 Polymerase Kit (Clontech) in accordance with the manufacturer's recommendations. Reactions of $50 \mu$ l contained $10 \times$ Advantage Taq PCR 2 Reaction Buffer (Clontech), $1 \mu$ of Advantage PCR 2 Taq DNA polymerase (Clontech), $1 \mu \mathrm{l}$ of template DNA (0.1 to $0.5 \mathrm{ng}: \mu \mathrm{l}), 10 \mathrm{pmol}$ of each primer, $1.25 \mathrm{mM}$ of each deoxyribonucleoside triphosphate. Thermal cycling for the amplification of products using the CTO primer set was carried out with an initial denaturation step of $95^{\circ} \mathrm{C}$ for $4 \mathrm{~min}$, followed by 30 cycles of denaturation at $95^{\circ} \mathrm{C}$ for $1 \mathrm{~min}$, annealing at $55^{\circ} \mathrm{C}$ for $1 \mathrm{~min}$ and elongation at $72^{\circ} \mathrm{C}$ for 2 min; cycling was completed by a final elongation step of $72^{\circ} \mathrm{C}$ for $4 \mathrm{~min}$. Thermal cycling for amplification using the universal primer set was carried out with an initial denaturation step of $95^{\circ} \mathrm{C}$ for $4 \mathrm{~min}$, followed by 20 cycles of denaturation at $95^{\circ} \mathrm{C}$ for $1 \mathrm{~min}$, annealing at $55^{\circ} \mathrm{C}$ for $1 \mathrm{~min}$ and elongation at $72^{\circ} \mathrm{C}$ for $2 \mathrm{~min}$; cycling was completed by a final elongation step of $72^{\circ} \mathrm{C}$ for $4 \mathrm{~min}$. The presence, size and concentration of the amplification products were checked by agarose $(1 \%)$ gel electrophoresis of the reaction product and ethidium bromide staining.

Denaturing gradient gel electrophoresis. DGGE was performed using the Dcode Universal Mutation Detection System (Bio-Rad Laboratories) according to the method for perpendicular gels in the Bio-Rad manual. Samples were initially run on a 20 to $80 \%$ denaturing gradient using an $8 \%$ acrylamide gel to find the optimum denaturant range. Samples were then re-run using a gradient of 40 to $70 \%$, which provided optimum band separation. $25 \mu \mathrm{l}$ of PCR product (all products had similar concentrations) (with $5 \mu$ of $5 \times$ DGGE gel loading buffer) was loaded and the gel run at $80 \mathrm{~V}$ and $60^{\circ} \mathrm{C}$ for $16 \mathrm{~h}$. The outer 2 lanes of each gel also contained a standard comprising a single sediment sample that allowed bands to be aligned. Gels were cooled then stained for 20 min using $10 \mu \mathrm{l}$ of $10000 \times$ SYBR Gold nucleic acid stain (Molecular Probes) in $100 \mathrm{ml}$ Tris-acetate EDTA (TAE) buffer (40 mM Trisacetate; $1 \mathrm{mM}$ disodium EDTA; $\mathrm{pH}$ 8). Gels were imaged using a UV transilluminator and digital images captured on a Kodak DC60 digital camera fitted with a 
deep yellow \#15 filter (Tiffen). Bands were excised using a sterile scalpel blade, placed in a microcentrifuge tube and washed with $200 \mu \mathrm{l}$ of sterile MilliQ for 30 min to avoid external DNA contamination from the gel surface. DNA was then eluted from excised bands by soaking in $200 \mu \mathrm{l}$ of STE buffer overnight at $37^{\circ} \mathrm{C}$.

Analysis of DGGE fingerprints. Individual bands were defined by a visually discernable signal above the gel background. Images of DGGE gels were analysed by assigning numbers to each of the bands present on the gel and then scoring each sample to define presence or absence of each band. Scoring of gel banding patterns resulted in a binary matrix containing presence or absence data for each set of samples. Statistical analyses were then performed on this matrix.

PCR re-amplification of DGGE band DNA. Duplicate DGGE bands were extracted from the same vertical positions but in different lanes from the DGGE gels. This was done to ensure that bands at the same position on the gels could be considered the same phylotype. A total of $1 \mu$ l of band eluent was re-amplified using primers 357f and 518r in the Hotstart PCR Kit (QIAGEN). PCR was performed with a $15 \mathrm{~min}, 95^{\circ} \mathrm{C}$ 'hotstart' step, followed by 25 cycles of $95^{\circ} \mathrm{C}$ for $1 \mathrm{~min}$, $55^{\circ} \mathrm{C}$ for $1 \mathrm{~min}$ and $72^{\circ} \mathrm{C}$ for $1 \mathrm{~min}$, with a final, $4 \mathrm{~min}$, $72^{\circ} \mathrm{C}$ step. Re-amplified DNA product was then purified using the Prep-A-Gene DNA purification system (Biorad) prior to sequencing.

Sequencing and similarity analysis. Direct sequencing of PCR products amplified from DGGE bands was carried out using the CEQ Dye Terminator Cycle Sequencing (DTCS) with Quick Start Kit (BeckmanCoulter). Reactions were carried out using a modification of the manufacturer's protocol; reactions were performed in $10 \mu \mathrm{l}$ volumes using $2 \mu \mathrm{l}$ of DTCS Quick Start Master Mix, $1 \mu \mathrm{l}$ of primer $\left(1.6 \mathrm{pmol} \mu \mathrm{l}^{-1}\right)$, and reactions were resuspended in $30 \mu \mathrm{l}$ of Sample Loading Solution (Beckman) after ethanol precipitation. Sequencing reactions were analysed using a Beckman CEQ2000 automated DNA sequencer, and electrophoretograms were manually checked and sequence data imported into a database using the BIOEDIT program (Hall 1999). Sequences were compared to sequences in the GenBank database (www.ncbi.nlm.nih.gov/blast) using the Basic Local Area Search Tool (BLASTn) (Altschul et al. 1997). Sequences from this study were then aligned to reference sequences obtained from GenBank, using the BIOEDIT program and ClustalW (Thompson et al. 1994, Hall 1999). The DGGE band sequences and BLAST reference sequences were then imported into and analysed using the software ARB (Ludwig et al. 1998). Similarity trees were calculated using maximum parsimony, based on long 16S rRNA sequences (more than $1300 \mathrm{bp}$ ) referred to in Stephen et al. (1996) and McCaig et al. (1999) and the latest SILVA alignment (Pruesse et al. 2007). The short DGGE band sequences (161 bp) were then inserted into the pre-established tree, using the ARB parsimony tool, and maintaining the overall tree topology without changes. The main aim of producing the similarity tree was not to produce or add to the phylogeny of the AOB (almost certainly not possible with a $161 \mathrm{bp}$ fragment), but to place the sequences from this study within the groups already identified as being potentially indicative of eutrophic conditions (Stephen et al. 1996, McCaig et al. 1999).

Sequences from this study have been deposited in GenBank under accession numbers EU295530 to EU295547

Real-time PCR. Real-time PCR was performed on farm sediment samples using primers specific for $\beta$ AOB. Standard curves were generated using a $\beta$-AOB sequence PCR fragment cloned from the sediments. DNA concentrations obtained from standard curves were converted to fragment copy number and ultimately $\beta$-AOB cell number assuming that all $\beta$-AOB have only one rrn operon (Hermansson \& Lindgren 2001). This has been shown for all $\beta$-AOB cultured so far (Aakra et al. 1999, Hermansson \& Lindgren 2001).

PCR reactions were performed in $20 \mu \mathrm{l}$ volumes using single $100 \mu \mathrm{l}$ strip tubes (Corbett Research). PCR reactions were performed using the Rotor-Gene thermocycler (Corbett Research), and data analysed using the Rotor-Gene software (version 5.0). Reactions were run in $20 \mu \mathrm{l}$ volumes containing $2 \mu \mathrm{l}$ of $10 \times$ Advantage Taq PCR 2 Reaction Buffer, $0.4 \mu$ l of Advantage PCR 2 Taq DNA polymerase, $0.4 \mu \mathrm{l}$ of template DNA $(0.1$ to $0.5 \mathrm{ng} \mathrm{\mu l}^{-1}$ ), $5 \mathrm{pmol}$ of each primer (either CTO189fA/ Bf and CTO654r or 519f [CAG CMG CCG CGG TAA TAC] and 907r [CCG TCA ATT CCT TTG AGT TT]) (Lane 1991), 1.25 mM of each deoxynucleotide triphosphate and SYBR Green nucleic acid stain (Molecular Probes) at a final concentration of 1:40000. Assays were performed using a 4 -step thermocycling program consisting of an initial $5 \mathrm{~min} 95^{\circ} \mathrm{C}$ incubation followed by 35 cycles of a denaturation step of $30 \mathrm{~s}$ at $95^{\circ} \mathrm{C}$, annealing of primers for $30 \mathrm{~s}$ at $55^{\circ} \mathrm{C}$, elongation for $30 \mathrm{~s}$ at $72^{\circ} \mathrm{C}$ with fluorescent acquisition, and a further fluorescent acquisition step at $80^{\circ} \mathrm{C}$. The temperature at which fluorescence analysis was performed was determined by examination of the melting profile of a number of samples, and performed at a temperature at which all primer dimer had melted, but the specific product had not $\left(80^{\circ} \mathrm{C}\right)$. Standards for calibration of the real-time PCR assay were added to each assay and included a dilution series of positive controls comprising AOB PCR fragments. Standard curves had $\mathrm{R}^{2}$ values $>0.99$ and results for all reactions were only con- 
sidered if reaction efficiencies were $>0.8$. Negative controls comprised template free reactions. All realtime PCR products were examined using agarose gel electrophoresis to ensure products corresponded to the correct size, and to ensure the absence of non-specific product. Samples were run in duplicate and analysis repeated if variance exceeded $10 \%$.

Univariate statistical analysis. Factorial ANOVA was used to test for the effect of farm (2 levels: cage and control) and time (3 levels: start of stocking period, end of stocking period, end of fallowing period) on $\beta$ AOB numbers over each yr. Normality and homogeneity of variances were checked visually by examining cumulative distribution and residual plots respectively. Data that did not meet these assumptions of ANOVA were log transformed. Significant factors were then compared using Tukey's HSD. All statistical tests were conducted at $\alpha=0.05$. The statistical software SPSS v10 was used to perform these tests. Results are reported as significant or non-significant results with the following notation: ' $F_{\mathrm{X}, \mathrm{Y}}=$ result', where $\mathrm{x}=$ the numerator degrees of freedom, $\mathrm{y}=$ denominator degrees of freedom and 'result' refers to the $F$ value returned in the test, followed by the $\mathrm{p}$ value.

Multivariate analysis. Multivariate analysis utilised the same factorial design as the univariate. Hence, the multivariate techniques described below were employed to test for the effect of farm ( 2 levels) and time (3 levels) on sediment community composition dynamics. The multivariate approach used in this study was similar to that advocated by Clarke \& Warwick (2001): (1) A visual representation of the community by hierarchical clustering, canonical analysis of principle coordinates (CAP) (Legendre \& Anderson 1999, Anderson 2003a) and non-metric multidimensional scaling (NMDS). An ordination plot is a 2dimensional representation of multidimensional data and therefore does not necessarily represent the data exactly. Simply, the closer samples are depicted to one another, the more similar they are. Samples with identical communities have symbols at the same location on the plots. The 'goodness of fit' in an NMDS plot is reflected in the plot's stress value; stress $<0.05$ represents an excellent representation, $<0.1$ a good representation, $<0.2$ still potentially representation, whereas $>0.3$ and the data points are close to being arbitrarily placed (Clarke \& Warwick 2001). In the results, when all visualisations agreed, we show the easiest to interpret plot. (2) Because the ordination plots are lower dimensional approximations of the full multivariate data set, we also conducted tests based on the full multivariate data tests to determine group separation. We discriminated samples using non-parametric multivariate analysis of variance (NPMANOVA) to test for significant interaction terms, followed by 1 -way analysis of similarity (ANOSIM) to investigate sources of significant differences if they were returned in the global test. ANOSIM also returns an R statistic indicative of how well groups are separated. $\mathrm{R}$ ranges between 0 (indistinguishable) and 1 (completely separated). Analyses were conducted using the software Primer 5.2.4, CAP (Anderson 2003a), NPMANOVA (Anderson 2003c; for balanced designs), (Anderson 2003d) and DISTLM v.2 (Anderson 2003b; for unbalanced designs). All multivariate statistical tests were tested at $\alpha=0.05$.

\section{RESULTS}

\section{Description of sediment samples}

Sediments from reference sites showed consistent visual characteristics throughout the $2 \mathrm{yr}$ trial period. They were characterised as brown, fine sediments that darkened in colour to black after several $\mathrm{cm}$. There were no apparent flocs or bacterial mats at the sediment surface (Bissett et al. 2007). Cage site sediments' appearance changed significantly throughout the trial. Organic matter loads to the sediment clearly increased over the stocking cycle. This visual increase in organic matter load was supported by significantly increased benthic respiration rates and total bacterial numbers at cage sites (Bissett et al. 2007). At the beginning of the trial, sediments appeared similar to those from reference sites. By the end of the stocking periods, the sediment appeared more reduced, exhibiting a darker, black colour throughout. Flocs were often observed at the surface, as were uneaten feed pellets, faeces and white Beggiatoa-like bacterial mats (Bissett et al. 2007). After the fallow periods, sediment appearance remained darker in colour to those at reference sites, but farm waste products were not observed and bacterial mats were less frequent. The oxygen penetration depths in ex situ cores decreased during stocking to be $\leq 1.5 \mathrm{~mm}$ in cage sediments compared to $>4 \mathrm{~mm}$ in reference sediments (Bissett et al. 2007) and ammonia was observed to build up in cage sediment during organic loading (Figs. $1 \& 2$ ).

\section{Infaunal analysis}

A total of 122 infaunal species were identified in this study, and the sediment communities were primarily characterised by a subset of only 32 species, which accounted for over $90 \%$ of the total abundance. Of this subset, 28 species and approximately $98 \%$ of individuals could be characterised as sediment destabilisers. Destabilisers comprised 83 to $85 \%$ of the reference 

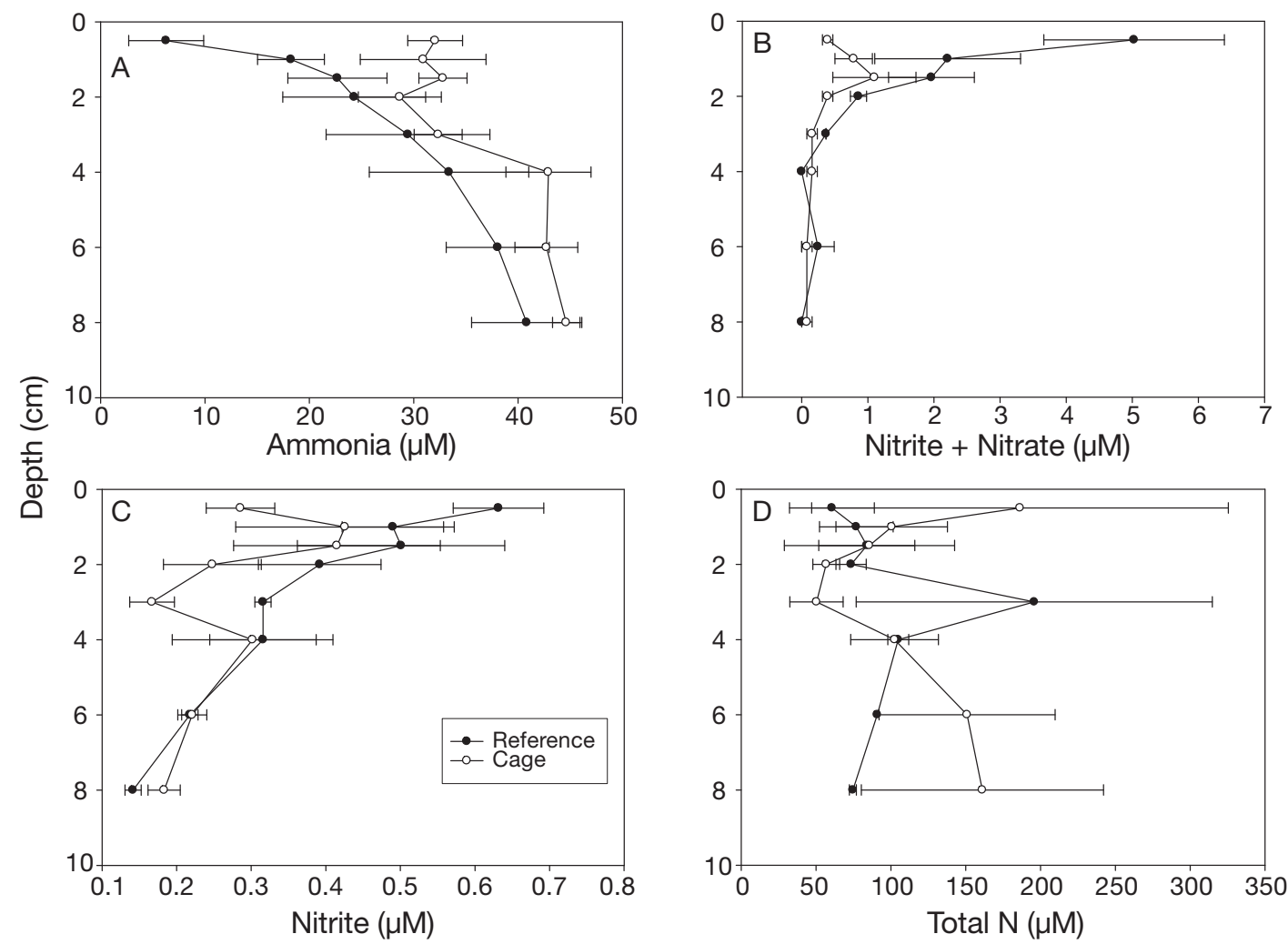

Fig. 1. Mean porewater concentrations $(\mu \mathrm{M})$ of $(\mathrm{A})$ ammonia, (B) nitrite + nitrate, (D) nitrite and (D) total N in cage and reference site sediments at the first sampling time $(\mathrm{S} 1) ; \mathrm{n}=3$. Scale bars represent $\mathrm{SE}$

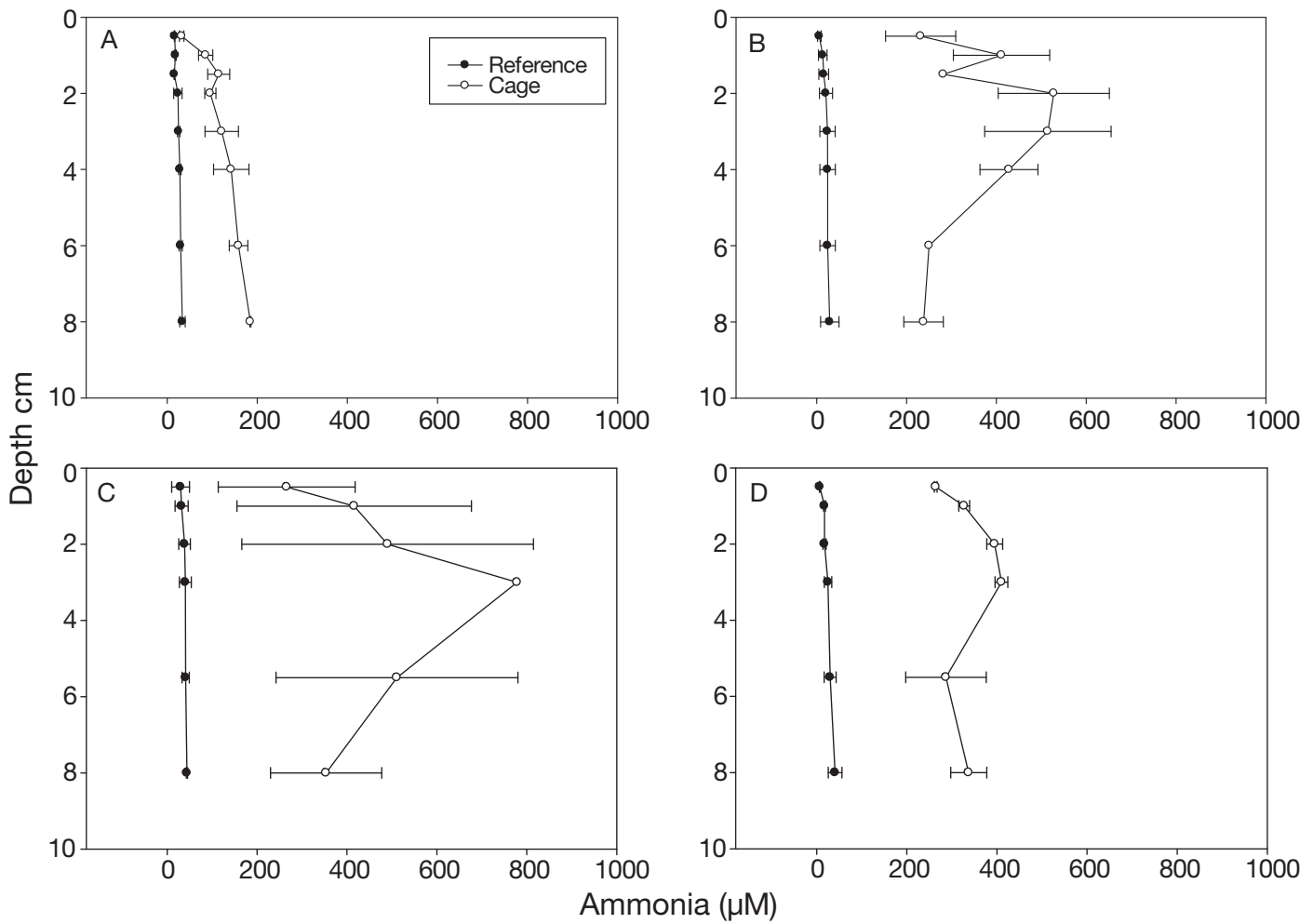

Fig. 2. Mean porewater ammonia concentrations $(\mu \mathrm{M})$ at cage $(O)$ and reference $(\bullet)$ sites at the end of the second stocking cycle $(A, B)$ and after the second fallowing period $(C, D) ; n=2$. Scale bars represent $S E$. In $(B)$ and $(C)$, no error bars indicate that only one core was analysed for that depth 
Table 2. Infaunal abundance from reference (R1, 4, 5, 7), prestocking (S1), stocked (S2, 3) and fallowed (S4, 7) sites, shown as the mean and standard error (SE) per sample, for the 2 main functional categories (destabilising, stabilising) and the total infauna

\begin{tabular}{|c|c|c|c|c|c|c|c|c|c|}
\hline \multirow{3}{*}{ Treatment } & \multicolumn{6}{|c|}{ Functional category } & \multicolumn{3}{|c|}{ All infauna } \\
\hline & \multicolumn{3}{|c|}{ Destabilising } & \multicolumn{3}{|c|}{ Stabilising } & & & \\
\hline & Mean & SE & $\%$ of total & Mean & $\mathrm{SE}$ & $\%$ of total & Total ind. & Mean & SE \\
\hline Reference & 78 & 4.6 & 85 & 14 & 1.4 & 15 & 2764 & 92 & 5.2 \\
\hline Prestocking & 83 & 5.9 & 83 & 18 & 5.3 & 17 & 605 & 101 & 8.3 \\
\hline Stocked & 8234 & 2382.0 & 100 & 1 & 0.4 & 0 & 41173 & 8235 & 2382.0 \\
\hline Fallowed & 88 & 30.6 & 99 & 1 & 0.2 & 1 & 1067 & 89 & 30.5 \\
\hline Total & 950 & 435.7 & & 10 & 1.4 & & 45609 & 959 & 435.4 \\
\hline
\end{tabular}

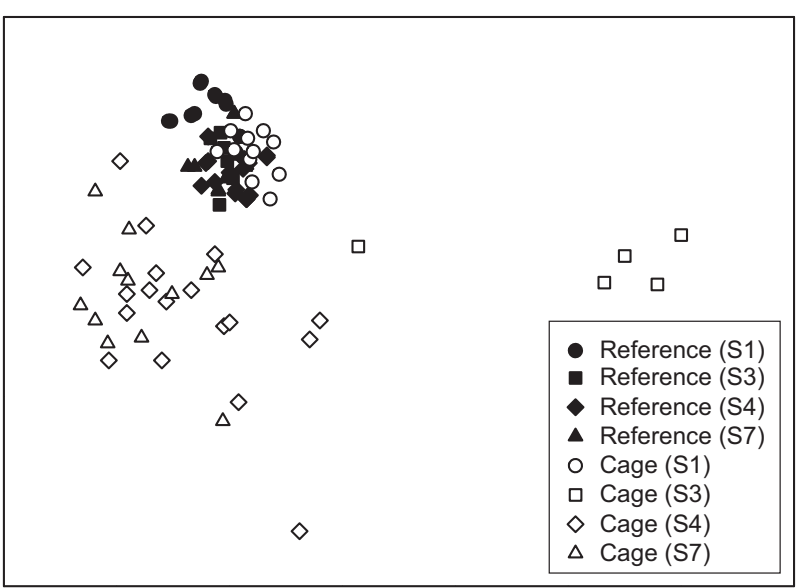

Fig. 3. NMDS plot showing the relationship between the sediment infaunal community at sites over time (S1 to S7). Timeline on the caged sites reflects the following production status: $\mathrm{S} 1=2 \mathrm{mo}$ (stocked), $\mathrm{S} 3=9 \mathrm{mo}$ (stocked), S4 = $12 \mathrm{mo}$ (fallowed) and S7 $=24 \mathrm{mo}$ (fallowed); stress $=0.09, \mathrm{n}=6$ (S3), 12 (S1, S7), 18 (S4). Samples with identical communities have symbols at the same location on the plots

communities at the start of the study; this increased to $100 \%$ after the onset of farming and remained high (99\%) over the fallow period (Table 2). NMDS analysis showed a clear change in the infaunal communities as a result of the increased organic loading (Fig. 3). Cage and reference site communities that were comparable at the beginning of the study were significantly different after organic loading $(R=0.936, p=0.002)$ (Fig. 3), becoming dominated by only 1 or 2 sediment bioturbators or destabilisers (Table 2), in particular the opportunistic species Capitella capitata and Nebalia longicornis (Macleod et al. 2006, 2007). The cage and reference communities remained significantly different throughout the fallow period; although the cage communities did improve over time, becoming more similar to the reference communities (lower R statistic, $\mathrm{R}=0.778$ ) (Fig. 3). Sediment stabilisers were almost exclusively located at the unimpacted sites (i.e. reference sites throughout the trial and cage sites prior to stocking), whilst destabilisers dominated where organic enrichment was greatest.

\section{Benthic nitrogen cycling}

Throughout the course of this study, the mean concentration of ammonia varied little ( 6 to $44 \mu \mathrm{M})$ in the sediment porewaters at the reference sites. Lowest concentrations were found in the top $2 \mathrm{~cm}$ and increased with depth. In contrast, porewater ammonia concentrations in cage sediments increased rapidly after cages were stocked with fish, to a mean concentration of $32.1 \mu \mathrm{M}$ at the surface (Fig. 1A). At the end of the first stocking period, surface sediments from the 2 cage sites had $161 \pm 67$ and $10253 \pm 1404 \mu \mathrm{M}$ ammonia whereas the reference sites had $24 \pm 2$ and $3 \pm 0.6 \mu \mathrm{M}$ respectively $(n=3)$. Initially, total $\mathrm{N}$ also increased in the surface sediments, but nitrite and nitrate declined in comparison to the reference sites during the first 2 mo of stocking (Fig. 1B-D). After the second 9 mo stocking period, the range of ammonia concentrations in the top $8 \mathrm{~cm}$ depth of sediment at cage sites was 32 to $788 \mu \mathrm{M}$, with only 3 samples containing less than $100 \mu \mathrm{M}$ ammonia (Fig. 2A,B). Fallowing for 3 mo had little effect on porewater ammonia concentrations, which remained much greater than at the reference sites (Fig. 2C,D).

Over the first 12 mo of this study, in which flux measurements in ex situ cores were made, there was a net flux of both nitrate and $\mathrm{N}_{2}$ out of the reference site sediments, such that denitrification likely accounted for about 40 to $60 \%$ of the $\mathrm{N}$ efflux (Fig. 4B-D) at all times with nitrate accounting for the residual efflux. Nitrogen dynamics during the same period were distinctly different at the cage sites (Fig. 4). Initially, cage sites showed a net efflux of nitrogen as $\mathrm{NO}_{3}{ }^{-}$with no denitrification occurring (Fig. 4B). After 6 mo of fish being stocked, there were net effluxes of both nitrate and $\mathrm{N}_{2}$, such that denitrification accounted for about $15 \%$ of the nitrogen efflux. However, towards the end of the stocking cycle (S3), nitrogen was predominantly lost 

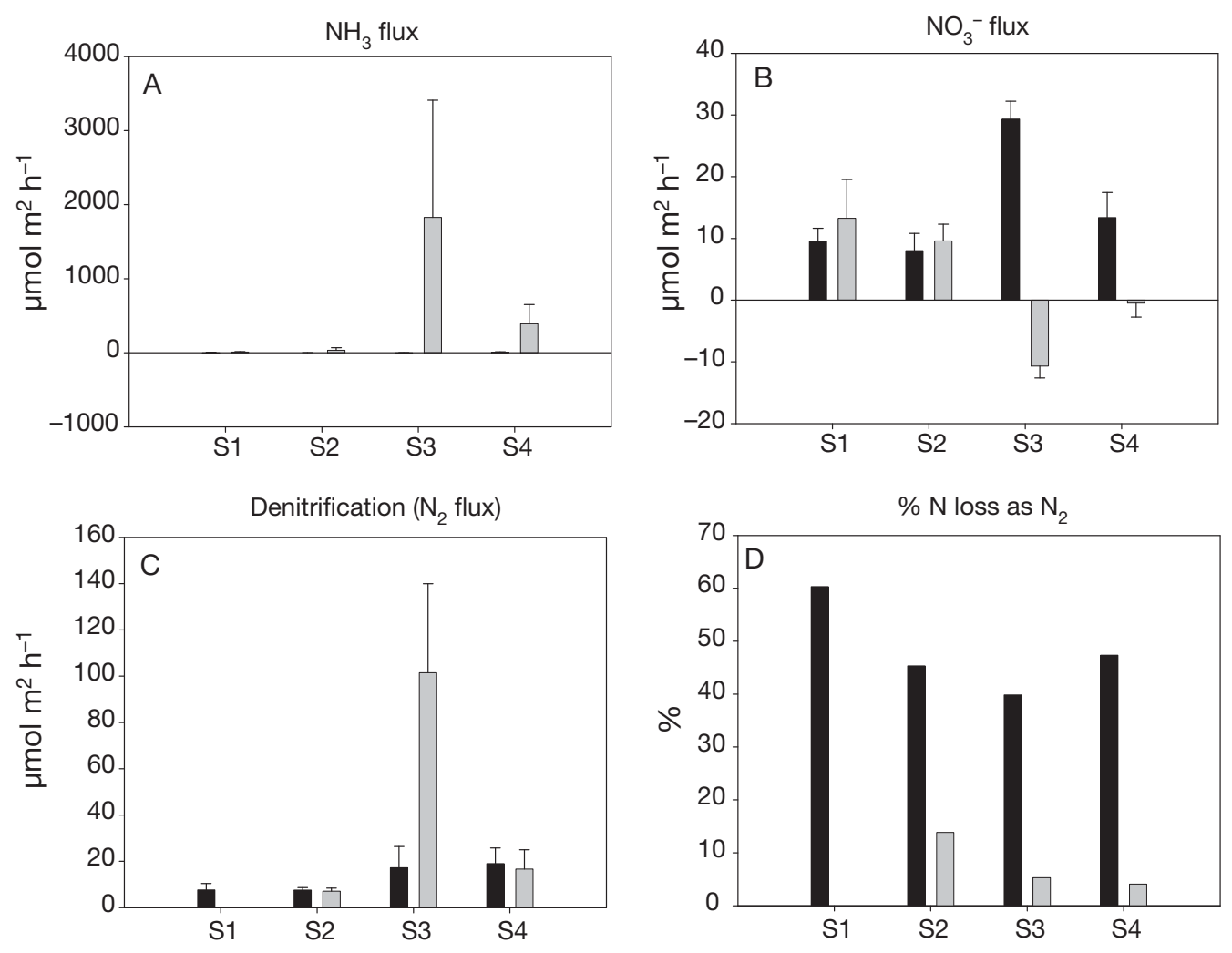

Fig. 4. Nitrogen dynamics in sediments. Dark bars refer to reference sites, light bars to cage sites. All data are from the first stocking cycle only. Note the different $y$-axis scales. Error bars represent standard error, $\mathrm{n}=3$. Denitrification was not measured at $\mathrm{S} 1$ for the cage site

from the cage sediments as $\mathrm{NH}_{4}{ }^{+}$and these sediments simultaneously became a net sink for $\mathrm{NO}_{3}^{-}$(Fig. 4). Denitrification rates increased dramatically and exceeded $\mathrm{NO}_{3}{ }^{-}$influxes from overlying water by a factor of 10 (Fig. 4). Despite this increase, denitrification at the cage sites accounted for $<15 \%$ of the total nitrogen efflux from the sediment at S3, because of the very high efflux of ammonia. Fluxes of total nitrogen were also measured under the cage sites and were in close agreement with the $\mathrm{NH}_{4}{ }^{+}+\mathrm{NO}_{3}{ }^{-}$fluxes, indicating fluxes of organic nitrogen were negligible (data not shown).

\section{$\beta$-AOB community composition shifts}

Average band number per treatment was similar across all samples and ranged from 8 to 9 bands at cages and 9 to 12 bands at reference sites. If average number of DGGE bands per gel (site) is used as a measure of richness, then both sites appear reasonably similar, although reference sites did show more bands per gel at all sampling times. Although band number was similar, band identity was variable. This is shown in the variation within and between treatments in Fig. 5.
Sediment $\beta$-AOB community composition was significantly affected by both treatment $(R=0.613, p=0.001)$ and time $(\mathrm{R}=0.424, \mathrm{p}=0.001)$ during the first $12 \mathrm{mo}$ farm cycle. No interaction effect was detected. Fig. 5A shows an NMDS plot of the $\beta$-AOB community data derived from the DGGE pattern. Reference and cage site communities differed from one another at all times. $\beta$-AOB communities at the beginning of the trial and after 9 mo of stocking did not differ significantly $(\mathrm{R}=$ 0.087, $\mathrm{p}=0.2$ ), but those after 3 mo fallowing had shifted significantly ( $R=0.406, p=0.001$ ) (Fig. 5A).

Over stocking cycle 2 there was a significant interaction between the effects of treatment and time on sediment $\beta$-AOB community composition $\left(F_{2,30}=7.5, \mathrm{p}=\right.$ 0.001) (Fig. 5B). The results of ANOSIM comparisons of treatment/time combinations are shown in Table 3. At cage sites, the $\beta$-AOB community showed greater variation and thus exhibited smaller shifts (lower R statistic) over the farming cycle. Cage site $\beta$-AOB communities differed from those at reference sites at the beginning of the trial, moved further away during the nine months for which cages were stocked and countershifted to approach the community at reference sites after the fallowing period. At reference sites, the community showed a shift over the 9 mo stocking period and a counter shift during fallowing. 

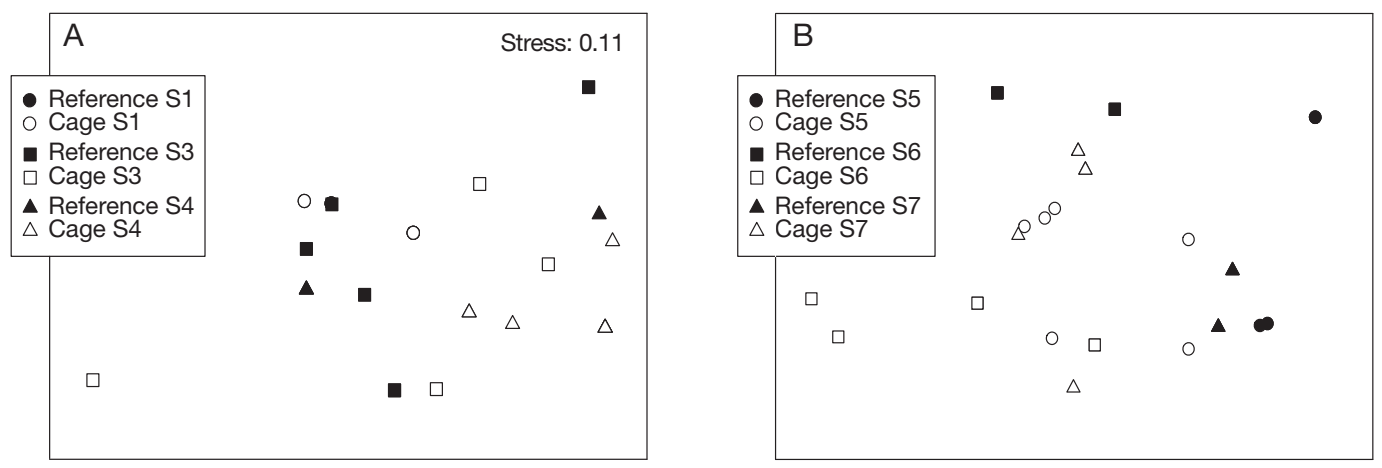

Fig. 5. (A) NMDS plot showing shifts in the sediment AOB community at a fish farm over the first stocking cycle. 2 mo (S1), 9 mo (S3), 12 mo (S4). (B) CAP plot of first 2 canonical axes of the sediment AOB community at a fish farm during the second stocking cycle. 12 mo (S5), 21 mo (S6) and 24 mo (S7); n = 6. Samples with identical communities have symbols at the same location on the plots
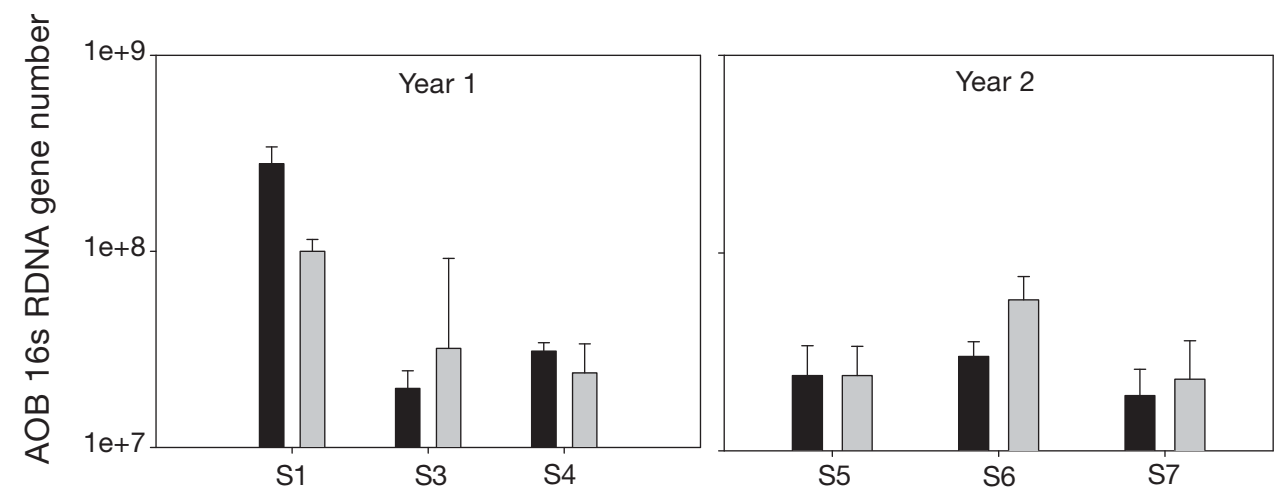

Fig. 6. Mean $\beta$-AOB 16S rDNA copies $\mathrm{g}^{-1}$ sediment $( \pm \mathrm{SE})$ at a fish farm over 2 production cycles. Dark bars refer to cage sites, light bars to reference sites; $\mathrm{n}=6$

Table 3. ANOSIM post hoc comparisons for the sediment $\mathrm{AOB}$ community at a fish farm during the second stocking cycle. S5 = $0 \mathrm{mo}, \mathrm{S} 6=9 \mathrm{mo}, \mathrm{S} 7=12 \mathrm{mo}$. Significance values in bold indicate a statistically significant result; $n=6$

\begin{tabular}{|lcc|}
\hline Site group & $\mathrm{R}$ & Significance \\
\hline Ref S5, Cage S5 & 0.400 & $\mathbf{0 . 0 2 9}$ \\
Ref S6, Cage S6 & 0.700 & $\mathbf{0 . 0 0 2}$ \\
Ref S7, Cage S7 & 0.256 & 0.074 \\
Ref S5, Ref S6 & 0.700 & $\mathbf{0 . 0 0 2}$ \\
Ref S6, Ref S7 & 0.500 & 0.49 \\
Ref S5, Ref S7 & 0.625 & $\mathbf{0 . 0 0 2}$ \\
Cage S5, Cage S6 & 0.116 & 0.152 \\
Cage S6, Cage S7 & 0.168 & 0.095 \\
Cage S5, Cage S7 & 0.257 & $\mathbf{0 . 0 5}$ \\
\hline
\end{tabular}

\section{$\beta$-AOB numbers}

During the first 12 mo cycle $\beta$-AOB numbers were affected by time $\left(F_{2,28}=10.994, \mathrm{p}=0.000\right)$ but not by organic loading from the farm: cage and reference site $\beta$-AOB numbers were not statistically significantly dif- ferent, but they changed over time. $\beta$-AOB numbers declined over the 9 mo stocking period and remained steady during the 3 mo fallowing period (Fig. 6). During the second farm cycle no significant effect of treatment or time was seen on $\beta$-AOB numbers. $\beta$-AOB numbers remained at a similar level to that seen at the end of the first cycle at both farm and reference sites (Fig. 6)

\section{DGGE band sequencing and $\beta$-AOB identities}

Representative bands generated from DGGE gels were excised and sequenced successfully. A total of 9 unique sequences were generated, all of which identified with the previously reported betaproteobacterial AOB clusters (Stephen et al. 1996, McCaig et al. 1999) (Fig. 7). The majority of the band sequences identified with the Nitrosospira groups, although some sequences grouped in the Nitrosomonas group. Sequences from both cage and reference sites were seen throughout the whole tree, with no treatment (organic 


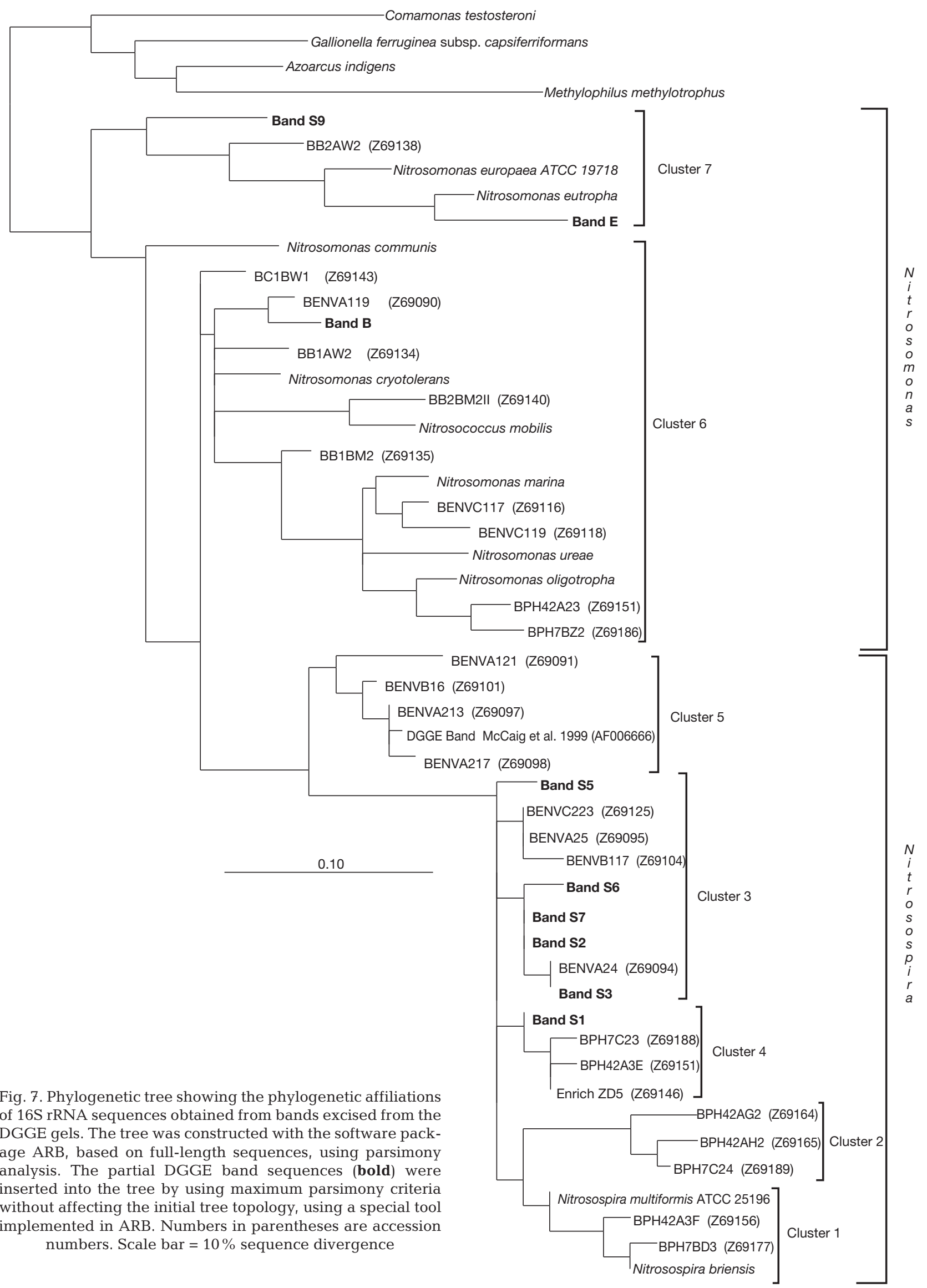


loading) driven differentiation between the sequence identities. Others (Stephen et al. 1996, McCaig et al. 1999) have reported the presence of sequences from betaproteobacterial AOB cluster 5 and attributed these sequences to organically enriched environments. No observed sequences from this study grouped strongly with these sequences (sequences EnvA121, EnvA213 and AF006666 in Fig. 7).

\section{DISCUSSION}

The aim of the study was to assess organic enrichment-induced shifts in the $\beta$-subgroup AOB community structure and $\mathrm{N}$ geochemistry in estuarine sediments around a fish farm. Organic loading was demonstrated by significantly increased sediment respiration (Bissett et al. 2007), increased sedimentation rates below the cages (Macleod et al. 2004) and increased sediment ammonia content. The effects of organic loading on $\beta$-AOB community structure were assessed by molecular methods, on nitrogen cycling by geochemical methods and on sediment structure by sediment infaunal community analysis. At this point we note that although the anammox (anaerobic oxidation of ammonium) reaction may have interfered with our measurements of denitrification using the isotope pairing technique (Risgaard Petersen et al. 2003), we believe anammox is not a significant process in this system. In a concentration series experiment (data not shown), wherein the rate of ${ }^{14} \mathrm{~N}$ denitrification was measured with different ${ }^{15} \mathrm{NO}_{3}{ }^{-}$concentrations at the reference site, ${ }^{14} \mathrm{~N}$ denitrification remained constant irrespective of the ${ }^{15} \mathrm{NO}_{3}{ }^{-}$concentration. If anammox rates were significant, then ${ }^{14} \mathrm{~N}$ denitrification should change as ${ }^{15} \mathrm{NO}_{3}{ }^{-}$concentrations increase (Risgaard Petersen et al. 2003). No concentration series experiments were performed on the impacted sites; however, anammox has a negative correlation with sediment respiration rates (Dalsgaard et al. 2005) and, hence, we suggest that the relative importance of anammox would decrease under the cages. Beggiatoa may accumulate $\mathrm{NO}_{3}{ }^{-}$(Hinck et al. 2007), and if there is a high turnover of this pool, then ${ }^{15} \mathrm{NO}_{3}{ }^{-}$would not mix homogenously with the pool of $\mathrm{NO}_{3}{ }^{-}$being denitrified, and hence the denitrification rates may be underestimated. We note there are no studies of this possible effect in the isotope pairing technique.

Under conditions of low organic loading (reference sites and cage sites at the start of the study [S1 and S2; Fig. 1]), the sediments studied typically released nitrate at about $10 \mu \mathrm{mol} \mathrm{m}{ }^{-2} \mathrm{~h}^{-1}$, as seen in ex situ cores. At the same time, the sediments were releasing similar amounts of $\mathrm{N}_{2}$, but relatively little ammonia (Fig. 4). This indicates that, as the major input of $\mathrm{N}$ to the sediments was organic $\mathrm{N}$, ammonification and coupled nitrification and denitrification were proceeding. Porewater profiles (Fig. 1) taken 2 mo after cages were stocked with fish support this: total nitrogen increased at the surface of the cage sediments, but nitrite and nitrate decreased at the surface. However, after 9 mo of stocking, there were substantial changes to nitrogen cycling processes at the cage sites. The surface-sediment ammonia concentrations were at least 5 times higher than the reference site concentrations and on occasion were much higher. Variably high values of ammonia illustrate the heterogeneity of the sediment, and increases in ammonia concentrations of this magnitude have been reported previously under fish farms (McCaig et al. 1999). By this time denitrification had increased by a factor of ca. 10, to a mean value of $100 \mu \mathrm{mol} \mathrm{m} \mathrm{m}^{-2} \mathrm{~h}^{-1}$, and simultaneously a very high ammonia efflux of $\left(1800 \mu \mathrm{mol} \mathrm{m}{ }^{-2} \mathrm{~h}^{-1}\right)$ was occurring. The measured influx of nitrate from the overlying water (Fig. 4B) was clearly insufficient to supply the measured rate of denitrification, indicating that nitrification must have been occurring in the sediments to supply oxidised $\mathrm{N}$ for denitrification. Furthermore, in the Huon Estuary, nitrate remains low from spring to early autumn, reaching maximum concentrations up to $5 \mu \mathrm{M}$ in the bottom waters during winter (Butler 2006). Thus, although nitrate from the water column may partially supply sediment denitrification at the end of the stocking cycle in spring (see nitrate uptake at S3 in Fig. 4B), there will be little nitrate to support denitrification during the fallowing period, as this occurs during the austral summer.

The high ammonia efflux at the end of the stocking period ( $95 \%$ of total $\mathrm{N}$ ) indicates that, although denitrification rates increased, only a small proportion of the total sedimentary ammonia was undergoing nitrification and subsequent denitrification. As organic matter loads and sediment respiration increased, so did benthic $\mathrm{NH}_{4}{ }^{+}$fluxes, and a diminishing fraction of $\mathrm{N}$ was lost from the sediment as $\mathrm{N}_{2}$. This outcome would be predicted by deterministic models of sediment $\mathrm{N}$ cycling (Soetaert et al. 2000) and can be simply explained by the reduced thickness of the oxic zone available for nitrification and a concomitant increase in the amount of ammonia passing through it. However, as denitrification is coupled to nitrification, then the rate of nitrification must have increased during peak sediment organic matter load, suggesting that favourable conditions for nitrification still existed within the sediments. Bissett et al.(2007) observed sharp increases in Beggiatoa-like bacterial numbers in cage sites at the end of the stocking cycle. The efflux of ammonia could have resulted from either or both of ammonification of organic-N or from dissimilatory nitrate reduction to ammonia by the Beggiatoa as 
reported by Christensen et al. (2000) for a Danish estuarine trout farm. The latter case would also require active nitrification in the sediments to supply the nitrate for sulphide oxidation by the Beggiatoa. Although we did not measure nitrification directly, all of the foregoing suggests that an active nitrifying population was maintained throughout the stocking and fallowing period, although the rates of nitrification relative to $\mathrm{NH}_{4}{ }^{+}$release from the sediment decreased.

DGGE analysis showed the effect by the organic loading from farming and a more general time/season affect on $\beta$-AOB communities. While we have not directly targeted ammonia oxidising archea (AOA) in our molecular analyses, lipid biomarker analysis of these sediments showed Crenarchaeaota to comprise only a small component of the community and that Crenarchaeota biomass did not change with organic loading (Macleod et al. 2004). We have therefore concentrated on AOB community analysis. However, we acknowledge that the AOA may indeed comprise a functionally significant proportion of the nitrifying community, even though they were not shown to be numerically dominant by lipid biomarker analysis. Such a result would not, however, alter our interpretation of the biogeochemical data presented but would add to the list of potential organisms carrying out ammonia oxidation.

We are aware of the pitfalls of applying phylogenetic inference to short sequence fragments such as those generated in this study. It is, however, valid to use short sequences to infer identity (Sogin et al. 2006); indeed they have proven valuable in investigations of bacterial communities. Sequences from both cage and reference sites were diverse and identified with sequences obtained from marine sediments and soil environments. No sequences identify with cluster 5 betaproteobacterial AOB sequences. Although sequences from this cluster have been associated with organically enriched fish-farm sediments (Stephen et al. 1996, McCaig et al. 1999), they have also been found in nutrient poor environments (Kowalchuk et al. 1997).

$\beta$-AOB population densities at cage and reference sites did not appear to be affected by farm operations but showed some natural variability with time. This is despite evidence that the sediment conditions under the cages changed markedly. In a parallel study (Bissett et al. 2007) we reported that no $\beta$-AOB sequences were found in 16S rRNA gene clone libraries. The coverage of the clone libraries was low (typical, despite the large clone numbers), and given the relatively low density of the $\beta$-AOB community, this is not surprising. Although absolute $\beta$-AOB numbers obtained by qPCR herein appeared relatively stable (Fig. 6), their contribution to the total microbial population declined dur- ing farming (Bissett et al. 2007). $\beta$-AOB are usually present only in relatively small numbers in the environment (Hermansson \& Lindgren 2001), and it was expected beforehand that the sediment conditions typical of fish farming would cause a decrease in $\beta$-AOB numbers and nitrification.

It is evident that interpretation of multivariate data concerning microbial diversity is difficult, especially when there is a temporal component to the study. Employing several multivariate techniques (NMDS, CAP, cluster analysis and significance testing) has aided in the interpretation of the above data. In terms of $\beta$-AOB diversity, as assessed with DGGE, it is evident that the sediments investigated in this study are very dynamic; that is, community composition appears to shift in response to both organic loading and temporal changes. The temporal stability of AOB communities over time is not well resolved. Sundberg et al. (2007), for example, found no temporal effect on AOB communities in their samples, despite changing $\mathrm{N}$ loads. However, de Bie et al. (2001) demonstrated that $\beta$-AOB populations are not necessarily stable over time, correlating changes in $\beta$-AOB population structure in the Schelde Estuary to changes in chemical gradients. In particular, the Nitrosomonas Cluster 6a dominated in deoxygenated, freshwater that was high in ammonia. As salinity and dissolved oxygen increased and ammonia decreased, a novel Nitrosomonas-like group dominated the community. The $\beta$-AOB communities in the D'Entrecasteaux Channel sediments studied here also appear to be very dynamic (as is the environment) at both cage and reference sites over time. Such community composition shifts are likely to be in response to changing environmental and sediment geochemical gradient conditions. There also appears to be a seasonal component to the variation in community composition. This seasonal component acts on both the cage and reference sites (independently of whether they were seen as the same or different) and is indicated by the significant effect of time often seen. What is clear at all sites and at all times is that $\beta$-AOB communities vary considerably. This variation shows that a wide variety of $\beta$-AOB phylotypes are present and suggests that different members could take advantage of changing conditions to dominate $\beta$-AOB communities at different times. In relation to oxygen concentrations in sediments, Kowalchuk et al. (1998) concluded that nitrifiers were generalists with varying degrees of tolerance to low oxygen. Thus, we conclude that there are sufficient phylotypes present to randomly fill changing niches, and so different physiological groups maintain nitrification potential. This argument is supported by the ability of nitrifiers to withstand long periods of dormancy (Kowalchuk et al. 1998) allowing different phylotypes to await 
favourable conditions. Previous studies investigating changing microbial communities have reported similar events; for example, Kaneko et al. 1977, as referenced in (Atlas \& Bartha 1998), found that, although the species reintroduced into arctic seas after winter ice melt may have been different to species present when the ice formed, the niches filled by these bacteria remained constant. The fact that the resident $\beta$-AOB communities is able to change rapidly and is diverse ensures that sediments maintain at least the potential for nitrification despite the apparently unfavourable conditions. This potentially enables sediments to 'catch up' with organic loading if fallow periods are managed, bearing in mind the apparent assimilative capacity of the resident rate-limiting communities.

Maintenance of AOB may have been related to the benthic fauna associated with conditions of nutrient enrichment, as these have been shown to enhance benthic production via bioturbation and bioirrigation (Heilskov \& Holmer 2001, Wu et al. 2003). The structure of the sediment infaunal communities shifted in response to the levels of organic loading. The community at the unimpacted locations was a mix of sediment stabilisers and destabilisers whilst in the cage sediments sediment stabilisers were all but absent and destabilisers dominated, indicating higher rates of bioturbation at these sites. During this study, the benthic fauna at cage sites became heavily dominated by opportunistic polychaetes, in particular Capitella spp., which have been shown to stimulate benthic microbial activity (Kristensen 1988). Sloth et al. (1995) reported that nitrification was maintained when organic carbon was mixed into sediment (mimicking bioturbation), but when the same organic carbon was deposited on the sediment surface, nitrification and denitrification were blocked. Microbial activity is stimulated by increased sediment oxidation, increased substrate surface area and the presence of organic rich faecal pellets and secreted mucoid products (Heilskov \& Holmer 2001, Wu et al. 2003). Sediments in this study did not become azoic at any point (Macleod et al. 2004). It is therefore likely that viable $\beta$-AOB populations were maintained in the oxidised conditions created by the macrofauna, as well as in the thin surface oxic zone in the sediments.

We have shown that $\beta$-AOB community biomass was maintained during periods of high organic loading and that the community continued to shift in composition throughout the study. Denitrification was seen to increase during organic loading, and simultaneously nitrate was taken up by the sediments, where previously there had been an efflux of nitrate. However, the influx of nitrate was insufficient to drive the observed denitrification; thus we infer that nitrification continued throughout organic loading despite sediment environmental conditions commonly considered detrimental. While we have not absolutely proven that the $\beta$-AOB are solely responsible for the supply of oxidised $\mathrm{N}$ in these sediments, the dynamic nature of the community would suggest they are at least viable. Regardless of the group performing nitrification (AOB or $\mathrm{AOA})$, continuance of nitrification under conditions commonly considered unfavourable may be due to (1) the capacity of nitrifying communities to adapt to rapidly changing sediment conditions, or (2) to the maintenance of suitable conditions by bioirrigating organisms, or a combination of both. We suggest that observed sediment efflux of nitrogen as ammonia occurred when organic inputs overwhelmed the capacity of the nitrifying community to convert ammonia to nitrate, rather than a failure (cessation of nitrification) of the community per se. Thus, although nitrification was probably maintained, or even possibly increased during organic loading, the proportion of ammonia that was nitrified was reduced. The consequence of this was that the sediments became a major source of ammonia, producing potential point sources of eutrophication.

Acknowledgements. This work formed part of a project of Aquafin CRC (now closed), and received funds from the Australian government's CRCs Program, the Fisheries R\&D Corporation and other CRC participants. This study could not have been completed without the assistance of the Aquafin CRC fallowing group, whose assistance with field sampling was invaluable. We thank A. Revill for assistance setting up the $\mathrm{N}_{2}$ isotopic measurements, R. Watson and D. Thomson for nutrient analyses and F. Schreiber for constructive comments on the manuscript. We also thank 2 anonymous reviewers for considerable input.

\section{LITERATURE CITED}

Aakra A, Utaker J, Nes I (1999) RFLP of rRNA genes and sequencing of the 16S-23S rDNA intergenic spacer region of ammonia-oxidizing bacteria: a phylogenetic approach. Int J Syst Bacteriol 49:123-130

Altschul SF, Madden TL, Schäffer AA, Zhang J, Zhang Z, Miller W, Lipman DJ (1997) Gapped BLAST and PSIBLAST: a new generation of protein database search programs. Nucleic Acids Res 25:3389-3402

Anderson MJ (2003a) CAP: a FORTRAN computer program for canonical analysis of principle coordinates. Department of Statistics, University of Auckland, New Zealand

Anderson MJ (2003b) DISTLM, Vol 2: a FORTRAN computer program to calculate a distance-based multivariate analysis for a linear model. Department of Statistics, University of Auckland, New Zealand

Anderson MJ (2003c) NPMANOVA: a FORTRAN computer program for non-parametric multivariate analysis of variance (for any two factor design) using permutation tests. Department of Statistics, University of Auckland

Anderson MJ (2003d) XMATRIX: a FORTRAN computer program for calculating design matrices for terms in ANOVA designs in a linear model. Department of Statistics, Uni- 
versity of Auckland

Atlas RM, Bartha R (1998) Development of microbial communities. In: Atlas RM, Bartha R (eds) Microbial ecology: fundamentals and applications. Benjamin Cummings, San Francisco, CA

Bissett A, Bowman J, Burke C (2006) Bacterial diversity in organically-enriched fish farm sediments. FEMS Microbiol Ecol 55:48-56

Bissett A, Burke C, Bowman JP, Cook PLM (2007) Bacterial community shifts in organically perturbed sediments. Environ Microbiol 9:46-60

Blackburn TH, Blackburn ND (1992) Model of nitrification and denitrification in marine sediments. FEMS Microbiol Lett 100:517-522

Butler ECV (2006) The tail of two rivers in Tasmania; the Derwent and Huon Estuaries. In: Wangersky P (ed) Handbook of environmental chemistry, Vol $5 \mathrm{H}$. Springer, Berlin, p 1-49

Christensen PB, Rysgaard $\mathrm{S}$, Sloth NP, Dalsgaard T, Schwærter S (2000) Sediment mineralization, nutrient fluxes, denitrification and dissimilatory nitrate reduction to ammonium in an estuarine fjord with sea cage trout farms. Aquat Microb Ecol 21:73-84

Clarke KR, Warwick RM (2001) Change in marine communities: an approach to statistical analysis and interpretation, 2nd edn. PRIMER-E, Plymouth

Craib JS (1965) A sampler for taking short undisturbed marine cores. ICES J Mar Sci 30:34-39

Dalsgaard T, Nielsen LP, Brotas V, Viaroli P and others (2000) Protocol handbook for NICE - nitrogen cycling in estuaries: a project under the EU research programme: Marine Science and Technology (MAST III), National Environmental Research Institute, Denmark, Silkeborg

Dalsgaard T, Thamdrup B, Canfield DE (2005) Anaerobic ammonium oxidation (anammox) in the marine environment. Res Microbiol 156:457-464

> Dang H, Zhang X, Sun J, Li T, Zhang Z, Yang G (2008) Diversity and spatial distribution of sediment ammonia-oxidizing crenarchaeota in response to estuarine and environmental gradients in the Changjiang Estuary and East China Sea. Microbiology 154:2084-2095

de Bie MJM, Speksnijder A, Kowalchuk GA, Schuurman T and others (2001) Shifts in the dominant populations of ammonia-oxidizing beta-subclass Proteobacteria along the eutrophic Schelde estuary. Aquat Microb Ecol 23: 225-236

Dong LF, Thornton DCO, Nedwell DB, Underwood GJC (2000) Denitrification in sediments of the River Colne estuary, England. Mar Ecol Prog Ser 203:109-122

Grasshoff K (1983) Methods of seawater analysis, 2nd edn. Verlag Chemie, Weinheim

Hall TA (1999) BioEdit: a user-friendly biological sequence alignment editor and analysis program for Windows 95/ 98/NT. Nucleic Acids Symp Ser 41:95-98

Heilskov A, Holmer M (2001) Effects of benthic fauna on organic matter mineralization in fish farm sediments: importance of size and abundance. J Mar Sci 58:427-434

Hermansson A, Lindgren PE (2001) Quantification of ammonia-oxidizing bacteria in arable soil by real-time PCR. Appl Environ Microbiol 67:972-976

Hinck S, Neu TR, Lavik G, Mussmann M, de Beer D, Jonkers HM (2007) Physiological adaptation of a nitrate-storing Beggiatoa sp. to diel cycling in a phototrophic hypersaline mat. Appl Environ Microbiol 73:7013-7022

Jensen KM, Jensen MH, Kristensen E (1996) Nitrification and denitrification in Wadden Sea sediments (Konigshafen, Island of Sylt, Germany) as measured by nitrogen isotope pairing and isotope dilution. Aquat Microb Ecol 11: 181-191

Joye SB, Hollibaugh JT (1995) Influence of sulfide inhibition of nitrification on nitrogen regeneration in sediments. Science 270:623-625

Kowalchuk GA, Stephen J, De Boer W, Prosser J, Embley T, Woldendorp J (1997) Analysis of ammonia-oxidizing bacteria of the beta subdivision of the class Proteobacteria in coastal sand dunes by denaturing gradient gel electrophoresis and sequencing of PCR-amplified $16 \mathrm{~S}$ ribosomal DNA fragments. Appl Environ Microbiol 63: 1489-1497

Kowalchuk GA, Bodelier PLE, Heilig GHJ, Stephen JR, Laanbroek HJ (1998) Community analysis of ammonia-oxidising bacteria, in relation to oxygen availability in soils and root-oxygenated sediments, using PCR, DGGE and oligonucleotide probe hybridisation. FEMS Microbiol Ecol 27:339-350

Kristensen E (1988) Benthic fauna and biogeochemical processes in marine sediments: microbial activities and fluxes. In: Blackburn TH, Sorensen J (eds) Nitrogen cycling in coastal marine environments, Vol 33. John Wiley \& Sons, Chichester, p 275-299

Lane DJ (1991) 16S/23S rRNA sequencing. In: Stackbrandt E, Goodfellow M (eds) Nucleic acid techniques in bacterial systematics. John Wiley \& Sons, New York, p 115-175

Legendre P, Anderson MJ (1999) Distance-based redundancy analysis: testing multispecies responses in multifactorial ecological experiments. Ecol Monogr 69:1-24

Leininger S, Urich T, Schloter M, Schwark L and others (2006) Archaea predominate among ammonia-oxidizing prokaryotes in soils. Nature 442:806-809

Ludwig W, Strunk O, Klugbauer S, Klugbauer N and others (1998) Bacterial phylogeny based on comparative sequence analysis. Electrophoresis 19:554-568

Macdonald RM (1986) Nitrification in soil: an introductory history. In: Prosser JI (ed) Nitrification. IRL Press, Oxford, p 1-16

Macleod CKA, Bissett A, Burke C, Forbes S and others (2004) Development of novel methods for the assessment of sediment condition and determination of management protocols for sustainable finfish cage aquaculture operations. Aquafin CRC, Adelaide, South Australia, http://www.tafi. org.au/publications/FRDC_2000_164_Aug04.pdf

- Macleod CK, Crawford CM, Moltschaniwskyj NA, Forbes SE (2006) Evaluation of short-term fallowing as a strategy for the management of recurring organic enrichment under salmon cages. Mar Pollut Bull 52:1458-1466

Macleod CK, Moltschaniwskyj NA, Crawford CM (2007) Biological recovery from organic enrichment: some systems cope better than others. Mar Ecol Prog Ser 342:41-53

Magalhães CM, Joye SB, Moreira RM, Wiebe WJ, Bordalo AA (2005) Effect of salinity and inorganic nitrogen concentrations on nitrification and denitrification rates in intertidal sediments and rocky biofilms of the Douro River estuary, Portugal. Water Res 39:1783-1794

> McCaig AE, Phillips CJ, Stephen JR, Kowalchuk GA and others (1999) Nitrogen cycling and community structure of proteobacterial beta-subgroup ammonia-oxidizing bacteria within polluted marine fish farm sediments. Appl Environ Microbiol 65:213-220

Muyzer G, de Waal EC, Uitterlinden AG (1993) Profiling of complex microbial populations by denaturing gradient gel electrophoresis analysis of polymerase chain reactionamplified genes coding for 16S rRNA. Appl Environ Microbiol 59:695-700

Nicol GW, Leininger S, Schleper C, Prosser JI (2008) The 
influence of soil pH on the diversity, abundance and transcriptional activity of ammonia oxidizing archaea and bacteria. Environ Microbiol 10:2966-2978

Nielsen LP (1992) Denitrification in sediment determined from nitrogen isotope pairing. FEMS Microbiol Ecol 86: 357-362

> Pruesse E, Quast C, Knittel K, Fuchs BM, Ludwig W, Peplies J, Glockner FO (2007) SILVA: a comprehensive online resource for quality checked and aligned ribosomal RNA sequence data compatible with ARB. Nucl Acids Res 35: 7188-7196

Purdy KJ, Embley TM, Takii S, Nedwell DB (1996) Rapid extraction of DNA and rRNA from sediments by a novel hydroxyapatite spin-column method. Appl Environ Microbiol 62:3905-3907

Risgaard Petersen N, Rysgaard S (1995) Nitrate reduction in sediments and waterlogged soil measured by ${ }^{15} \mathrm{~N}$ techniques. In: Alef K, Nannipieri P (eds) Methods in applied soil microbiology and biochemistry. Academic Press, London, p 287-295

Risgaard-Petersen N, Nielsen LP, Rysgaard S, Dalsgaard T, Meyer RL (2003) Application of the isotope pairing technique in sediments where anammox and denitrification coexist. Limnol Oceanogr Meth 1:63-73

Santoro AE, Francis CA, de Sieyes NR, Boehm AB (2008) Shifts in the relative abundance of ammonia-oxidizing bacteria and archaea across physicochemical gradients in a subterranean estuary. Environ Microbiol 10: 1068-1079

Sloth NP, Blackburn H, Hansen LS, Risgaard-Petersen N, Lomstein BA (1995) Nitrogen cycling in sediments with different organic loading. Mar Ecol Prog Ser 116:163-170

Soetaert K, Middelburg JJ, Herman PMJ, Buis K (2000) On the coupling of benthic and pelagic biogeochemical models. Earth Sci Rev 51:173-201

Sogin ML, Morrison HG, Huber JA, Welch DM, Huse SM,

Editorial responsibility: Ronald Kiene,

Mobile, Alabama, USA
Neal PR, Arrieta JM, Herndl GJ (2006) Microbial diversity in the deep sea and the underexplored 'rare biosphere'. Proc Natl Acad Sci USA 103:12115-12120

Stephen JR, McCaig AE, Smith Z, Prosser JI, Embley TM (1996) Molecular diversity of soil and marine 16S rRNA gene sequences related to beta-subgroup ammoniaoxidizing bacteria. Appl Environ Microbiol 62:4147-4154

Sundberg C, Stendahl JSK, Tonderski K, Lindgren PE (2007) Overland flow systems for treatment of landfill leachates-potential nitrofication and structure of the ammonia-oxidising bacterial community during a growing season. Soil Biol Biochem 39:127-138

Thompson JD, Higgins DG, Gibson TJ (1994) CLUSTAL W: improving the sensitivity of progressive multiple sequence alignment through sequence weighting, positions-specific gap penalties and weight matrix choice. Nucleic Acids Res 22:4673-4680

> Valderrama JC (1981) The simultaneous analysis of TP and TN in natural waters. Mar Chem 10:109-122

> Watson RJ, Butler ECV, Clemenston LA, Berry KM (2005) Flow injection analysis with fluorescence detection for the determination of trace levels of ammonium in seawater. J Environ Monit 7:37-42

Wertz S, Degrange V, Prosser JI, Poly F, Commeaux C, Guillaumaud N, Le Roux X (2007) Decline of soil microbial diversity does not influence the resistance and resilience of key soil microbial functional groups following a model disturbance. Environ Microbiol 9:2211-2219

- Wildish DJ, Hargrave BT, Macleod CKA, Crawford CM (2003) Detection of organic enrichment near finfish net-pens by sediment profile imaging at SCUBA-accessible depths. J Exp Mar Biol Ecol 285-286:403-413

Wu SS, Tsutsumi H, Kita-tsukamoto K, Kogure K, Ohwada K, Wada M (2003) Visualization of the respiring bacteria in sediments inhabited by Capitella sp. 1. Fish Sci 69: $170-175$

Submitted: December 19, 2008; Accepted: July 21, 2009 Proofs received from author(s): September 24, 2009 